\title{
Adalék a kérés pragmatikájához - egy 16. századi magánlevél kapcsán
}

\author{
Hegedüs Attila \\ PPKE Magyar Nyelvészeti Tanszék
}

\begin{abstract}
Összefoglaló
A rövid tanulmányban egy 16 . századi magánlevélben megfogalmazott kérést elemzek a történeti szociopragmatika szemszögéböl. A kérés pragmatikájának általánosabb áttekintése után a szövegvizsgálat szempontjait mutatom be, kitérve az eddigi gyakorlat kritikai ismertetésére. Az adott kor levelezésének ismerete a korban használt formulák értékelését is befolyásolja, továbbá hangsúlyt kap a levelezésben részt vevők társadalmi és rokoni kapcsolatának bemutatása is. A vizsgálat alapján nyilvánvalóvá válik, hogy a kérés megfogalmazása, a felhasznált nyelvi elemek és az alkalmazott eljárásmódok lényegében nem térnek el a ma is élő gyakorlattól, csupán az érvelő technika 16. századi élőbeszédbeli megjelenése tűnik mai szemmel redundánsnak. A kor viszonyainak ismerete (az adósság visszafizetése, illetőleg a hitelbe adott javak visszaszerzésének gyakorlata) alapján azonban a mai ember számára túlzsúfoltnak, redundáns ismétlésnek tűnő frázisok szerepének valós értékelése válik lehetővé.
\end{abstract}

Kulcsszavak: történeti szociopragmatika; kapcsolatrendszer; redundancia; a kérés pragmatikája; performatívumok

\section{A történeti pragmatika}

A történeti pragmatika a nyelvészetben - amint ezt Sárosi Zsófia leírja (2015: 132) - egy 1995-ben megjelent kötettel vette kezdetét. Hazai propagálója, Sárosi Zsófia már 1985-ben a személyek közötti viszony elemzését fontosnak tartva közölte már akkor is szociopragmatikai elveket tartalmazó írását (Sárosi 1985). Én pedig a rá következő évben írtam egy „programkijelölő” tanulmányt Történeti szociolingvisztika? címen (Hegedűs 1986). Mindketten a kezünkben levő történeti anyag vizsgálata alapján fogalmaztuk meg nézeteinket, amelyek így visszatekintve az ún. pragmafilológia körébe tartoztak: erőteljesen bennük volt a történeti szövegek szociokulturális meghatározottságának a gondolata. Hadd idézzek röviden ebből az 1986-os írásomból (Hegedűs 1986: 440):

„a történeti nyelvszociológia feladatát abban látom, hogy mindenekelőtt írja le a vizsgált csoportot (történeti adatok alapján) minél teljesebben. Írja le a csoport tagjai közti viszonyokat, mindazt, ami a nyelvhasználatot befolyásolhatja. Figyeljen mindarra - amennyiben ez lehetséges -, amire a mai modern, szituációs nyelvjárásvizsgálat figyel: a csoport összetételére, az adatközlés jellegére, az adatközlő befolyásoltságára, az adatközlő társadalmi meghatározottságára és egyéni jellemvonásaira. A mai nyelvjárási adatfelvétel tág 
lehetőségeit természetesen nem találjuk meg a történeti szövegekben, de mindenesetre az egykori „adatközlői” (= levélírói) szituáció minél több összetevőjét ki kell derítenünk. Véleményem szerint így tehetünk leginkább eleget annak a kívánalomnak, hogy az egykori funkcionáló nyelvet mutassuk be."

Egy ilyen vizsgálat, amint e tanulmány további részében írtam, szükségszerűen a makrostruktúra felöl kell, hogy közelítsen a nyelvi anyaghoz. A történeti szociopragmatika ehhez a korai felfogáshoz képest egy további, sajátos, mondhatni leszükítő lépést hangsúlyoz: azt ugyanis, hogy vizsgálandó alapvetően az, hogy „a beszélő az adott közösség tagjaként hogyan használja a rendelkezésére álló forrásokat arra, hogy megváltoztassa a dolgok állását” (Sárosi 2015: 135). A következőkben tehát, amint a címben is jeleztem, egy 16. századi magánlevél (misszilis) elemzésével kísérlem meg a kérés pragmafilológiai elemzését: hogyan, milyen nyelvi eszközöket alkalmazva akarja rávenni a levélíró az édesanyját egy számára kellemetlen lépés megtételére.

\section{A kérés pragmatikája}

Mielőtt azonban erre rátérnénk, vizsgáljuk meg, mi tartozik a kérés pragmatikájának tárgykörébe. A kérés a beszédaktusok közé tartozik, Austin szerint a végrehajtók közé (Austin 1990), „illokúciós ereje a beszélőnek hallgatójával szembeni jövőbeli elvárásaival azonosítható" (Szili 2002: 19). A kérés aktusa az egyes kultúrákban nem azonos módon jut kifejezésre, a magyarban elsődleges a direkt felszólítás és kérés, amely a kötőmód speciális formája (pl. Zárd el a csapot!), a kérés szándékát jelölő ige modális (segéd)igével (El szeretném kérni.), és az ún. „konvencionális stratégia" (Fel tudná váltani?). Amint Szili Katalin írja, a kérés explicit formája, a kérek/kérem performatívummal alkotott forma a mai magyarban nem elsődleges megjelenítője ennek a beszédaktusnak, előfordulása nagyjából 10\% körüli az összes performatívum között. Szili kiemeli továbbá, hogy a kérés pragmatikája szempontjából lényeges elem a beszélő és a hallgató közötti társadalmi távolság: minél kisebb ez a távolság, annál inkább megjelenik a direkt felszólítást képviselő stratégia. Ez a stratégia súlyos kérések esetében megkívánja, hogy a kérő a kérést megokoló, magyarázó, támogató megnyilatkozásokat is bevessen a cél elérése végett. Összegzésében Szili megállapítja, hogy a magyarul beszélők kéréseiben „pontosan tükröződik a felek közötti társadalmi kapcsolatok minősége”, alá-fölérendeltségi viszonyaik, továbbá, hogy a direkt performatívumok alkalmazása együtt jár az ezeket enyhítő udvariassági elemek változatosságával.

A kérésre irányuló, magyar történeti anyagon megvalósuló vizsgálatok egy részének (Koós 2008; Krepsz 2015) közös vonása, hogy nagy nyelvi anyagon történnek, de elnagyolják a társadalmi kapcsolatok elemzését (nehéz is lenne 1027 [Krepsz] levél szereplői emberi kapcsolatainak számbavétele). A nyelvhasználatból indulnak ki (mást nem tehetnek), az önmegnevezések, a megszólítások, a kérés témája nyelvi megformálását vizsgálják tehát. A konkrét kérés konkrét hátterének teljesebb megvilágítása hiányában azonban ezek a vizsgálatok több esetben is meglátásom szerint - a felszínen maradnak csupán. A társadalomtörténeti háttér felvázolása a nyelvtörténeti kutatásokban ugyanis ugyanolyan fontos, mint a szociológia eredményeinek felhasználása az élőnyelvi kutatásokban (vö. Németh 2008: 
17). Egy ilyen jellegű megközelítést olvashatunk Bácsi Enikő tanulmányában (Bácsi 2015). A szerző a levelek értékelése előtt részletesen bemutatja a személyeket, egymáshoz való viszonyukat, ez után már megokoltak lesznek azok a megjegyzések, következtetések, amelyeket levon a két fél levelezéséről. A szerző ugyanis egy házaspár levelezését vizsgálva utal a férfi-női kérés megformálásának különbségeire, s ezt a két fél eltérő körülményeivel magyarázza (a férfi, Nádasdy Tamás az ország egyik első embere, felesége pedig leginkább otthon tartózkodik, „nem lát bele a férfi távoli életébe"(86)).

\section{A vizsgált nyelvi korpusz bemutatása}

A vizsgálandó nyelvi korpusz: Középkori leveleink (a továbbiakban KI.) (HegedűsPapp 1991) 27. sz. levél. A betűhív közlést a könnyebb vizsgálhatóság érdekében átírtam egy stilizált, korabeli kiejtést tükröző változatra, továbbá a levél folyamatosan írott szövegét mondatokba tördeltem.

„Én szerető asszonyom és én édes szilém! Írom kegyelmednek szolgálatomat és imádságomat. Továbbá könyörgök kegyelmednek, mint én édes szilémnek, hogy kegyelmed menjen el Besztercére Mihály uramhoz. Mert én eleget szóltam vele, és az(t) fogadá, hogy semmiképpen egyebet benne nem teszen, hanem azmennyi pínzt kegyelmed tőle kéretett, megadja, és még többet ád. És higgye kegyelmed, hogy nem csak egyszer mondotta én előttem. És ugyan sírt, hogy míg él, mindaddig bánja azmit kegyelmeden tött, és ennek utána minden szolgálattal lészen kegyelmednek. Mert én ugyan nyilván szóltam neki, és azt mondottam, hogy talám csak az ezt kívánja, hogy kegyelmed oda menjen, hogy azminemő szerzést kegyelmetek között vagyon, hogy azt megbontsa, és azmennyi pínzbe megszerződtetek, azt megkevesíhe. De azt mondotta nekem nagy eskéssel és átokval, hogy soha csak ígyen sem gondolta, és ha azt teszi kegyelmed, hogy mostan oda mégy, még azmely napra az urak szerzették volt az fizetést, aznak előtte, teljességvel megfizet kegyelmednek. Azért én édes szilém, könyörgök kegyelmednek, hogy kegyelmed benne egyebet ne tegyen, hanem elmenjen. Mert tudja kegyelmed, hogyha el nem mégy, kárt vallasz. Mert Sárkány Ambrus es két fő szolgáját küldötte vala hozzám, és ugyan istenébe kérete, hogy megírjam kegyelmednek, hogy elmenjen kegyelmed. Mert jól tudja kegyelmed, hogy ha Mihály uram akarja, még két vagy három esztendeig elvontathatja az fizetést. Azért kérlek az istenért én édes szilém, hogy egyebet benne ne tégy, hanem elmenj. Mert én azt esmérem, és önmaga es azt mondja, hogy ha kegyelmed odamegyen, és ebbe neki akaratját teszed, ő es mindazt teszi vala, mit kegyelmed akar. Azt es mondá, hogy jól tudja ő, ki dolga ez, hogy kegyelmed oda nem akar menni. De isten, szent Mihály őtet úgy segélje, hogy ha el nem mégy, még két esztendeig es az pínzt olvassák, kit ő ád. De ha elmégy még az szerzett napnak előtte, teljességvel megadja mind az ötezer forintot. Azért én édes szilém, kérlek meges, hogy egyebet benne ne tégy, mert annyira fogadott nekem, hogy én felelek felőle, hogy ez mostani várásod hiába nem lészen. Mert tudja kegyelmed, hogy én jeles emberekvel szóltam ez felöl, kik mind jól tudnak az morvai törvényhez, és mind megmondák, mint árthat ő 
még, és mivel elhalaszthatja, ha akarja, az fizetést két vagy három esztendeig, kit meg es teszen, ha ebbe kegyelmed neki akaratját nem teszi. Ha mind megírnám, minemő szókat nekem szólt és minemő fogadásokat tött, három árkos papirosra nem férne. De végre ezt mondá, hogy kérjem kegyelmedet ő szavával, hogy ha azt akarja kegyelmed, hogy ő mind éltig szolgálja kegyelmedet, hát kegyelmed hagyja el az sok apró ember tanácsát, és tegye akaratját ebbe neki, és valamit akar és parancsol kegyelmed, mind aztevő lészen. Továbbá néném es levelet küldö vala, és az es istennek szent haláláért kéretett, hogy megírjam, hogy kegyelmed benne egyebet ne tegyen, hanem elmenjen, mert mindazt teszik, mit kegyelmed akar. Azért ím én megírtam, és ha mi bántása lészen kegyelmednek, senkire ne vess, hanem csak ten magadra. Isten tartsa ő szent malasztjába kegyelmedet.

Barbara, az néhai nagyságos Tárczai János leánya"

Címzés: „Sára asszonynak, az néhai nagyságos Tárczai Jánosnénak, én szerető szilémnek adassék ez levél"

\section{A környezet és a kor behatároló szerepe, a levél létrejöttének körülményei, érintettjei}

A szöveg szereplői: 1. a levélíró Tárczai Borbála, 2. az édesanyja, özvegy Tárczai Jánosné, 3. a levélíró nénje, 4. Mihály uram, 5. Sárkány Ambrus (két fő szolgája közvetítésével). Mit tudunk róluk és a kapcsolatrendszerről, amely őket összeköti? A szereplők zömmel ugyanannak a családnak a tagjai: az özvegy édesanya, Bethlen Sára előkelő családban nőtt fel, férje pedig magas tisztségeket viselt (Tárczai János 1492-ben zempléni ispán, 1504-1506 között erdélyi ispán volt). Hozzászokhatott tehát az őt megillető tisztelethez. A levélíró Tárczai Borbála apáca volt, 1523-ban engedélyt kap arra, hogy a budai kolostorból egy másik kolostorba költözzön. Mint a főúri rendből származó apáca társait, valószínüleg őt is jobban érdekelték a világi ügyek, családi események, mint az imádság: egy másik magyar nyelvű levelében (KI. 26. sz.) arra kéri édesanyját, küldjön neki pénzt, hogy a zsidóknál zálogba tett értékeket kiválthassa, és a gyöngyfüzőt kifizethesse. Nénje, Tárczai Katalin Podmaniczky Mihály felesége. S itt jön a képbe Podmaniczky Mihály, az említett „Mihály uram”. Királyi udvarnok, 1517-ben kamarás, haláláig (1526) a királyi gyalogos testörség kapitánya. Anyós és vő között a kapcsolat napjainkban is számos esetben sem felhőtlen, gyakran ambivalens. Ez az anyós-vő kapcsolat kap történetünkben sajátos színezetet. (Sárkány Ambrus személye történetünkben mellékszál. Főúr, a kor jelentős alakja, pozsonyi, majd zalai ispán, 1524-25-ben országbíró. Tekintélyes ember tehát, akinek szavára érdemes figyelni.)

Az előzmény: Podmaniczky Mihály különféle adósságok ellenértékeként zálogba adja anyósának a báni várkastélyt, és 1524 . december 21-én át is adja neki a kastélyt. Ennek 10 nap múlva ellentmond fivére, Podmaniczky István nyitrai püspök. Per kerekedik, s a pert „Mihály uram” elveszíti 1525. február 12-én. Adósságát vissza kell fizetnie anyósának, a levélben említett ötezer forint valószínüleg erre vonatkozik. Adósságot visszafizetni, illetőleg ezt megkapni azonban ma sem egyszerű, és az adott korban sem könnyü eset. A KI.-ben több levélben is előfordul az adósság, az ennek fejében zálogba adott javak kiváltása, a biztosítékként megírt 
záloglevelek, a visszafizetés problémája: vö. Drágffy János végrendelete: KI. 50. Sz., Batthyány Ferenc levelei adósságba keveredett unokaöccséhez: KI. 178, 191. sz.; a diák Sulyok Ferenc [KI. 210. sz.] anyjához írott, pénzt kérő levelében arról ír, hogy a neki hitelező mester „óránként kéntat, ha hoztak valamit neki”, és a doktor is „könyörög” az őt megillető javadalmazásért. Érdemes kissé hosszasabban idéznünk Zsegnyei László 1530-ban írt levelének részletét (KI. 95. sz.), mert jól mutatja a helyzetek párhuzamosságát, és a megoldás (a kölcsön visszafizetésének) lehetöségét: a levélíró Thurzó Elekről szólva írja [a szöveget a Tárczai-levél mintájára átalakítottam]:

„Most ő oda nem mehet, azt mondja, mert király adós neki vagy két ezer forinttal, és az régenteknek hagyta, hogy mikoron pínzek leszen, hogy ők adnák meg. Most pínzek nincsen, hanem azt mondták, hogy mikoron leszen, akkoron ott legyen, és megadják. Ő ott Bécsben egy embert hagyott, és ott tartja, hogy mikoron az pínzt elhozzák, legottan ide jő, és őneki megmondja. Ő csak egy óráig sem késik, legottan oda megyen Bécsbe, mert ha személy szerint ott nem lenne, egy pínzt sem adnának neki. Ez az oka, mért oda te kegyelmedhez nem mehet, mert ha akkor jutna az ember Bécsből, mikoron ő hon nem volna, tahát annyi kárt vallana, mint annyi summa pínz."

Aki nem fizet, az vagy nem tud, vagy nem akar fizetni. Tárczai Borbála józanul méri fel a lehetőséget: a „morvai törvény” ismeretében anyjának meg kell tennie a nevezett gesztust, hogy megkaphassa pénzét.

\section{Az alkalmazott stratégiák értékelése}

A levélíró stratégiája:

1. Az önmegnevezés, megszólítás, kapcsolatra utalás kérdése. Ez a kérdés a hivatkozott történeti szociopragmatikai munkákban erőteljesen jelenik meg. Tárczai Borbála és édesanyja esetében az anya-lánya viszony az uralkodó elem, az erre utaló s a levélben ötször előforduló „édes szilém” e viszonyt nyomatékosítja. Érdemes azonban megfigyelni, hogy a levél folytonosságában hol szerepelnek ezek a szerkezetek: egyszer a címzésben, egyszer a megszólításban, három további esetben pedig kétszer a „könyörgök” nyomatékosításában, egyszer pedig a „kérlek” közvetlen közelében. Mindig olyankor, amikor szükséges e viszony hangsúlyozása.

2. A felszólító mód alkalmazása. Szili Katalin szerint ez a legközvetlenebb stratégia. Ez a forma levelünkben (el/oda)menjen (el) alakban jut kifejezésre. Öt alkalommal használja ezt a módot a levélíró, és éppen azért teheti meg, mivel az említett közeli viszony ezt lehetővé teszi.

3. Az explicit performatívum alkalmazása. Két esetben a könyörgök, öt esetben pedig a kér ige szerepel ebben a szerepben, ez utóbbi kétszer közvetlenül, kétszer pedig közvetetten, más szavát idézve: egyszer Sárkány Ambrus, egyszer pedig a nénje szavát idézi, mindkettő kérete, hogy megírjam. Egy ötödik alkalommal pedig maga az adós mondá, hogy kérjem kegyelmedet áll a szövegben.

4. Javaslattevő forma alkalmazása. E formát a levélben a megyige képviseli, amely a szövegben egyébként 12 alkalommal szerepel, és mint javaslattevő forma ha el/oda mégy, illetőleg ha el nem mégy alakban olvasható. Mindkét esetben mellette 
találjuk a pozitív kifejlet megcsillantását (megfizet, megadja, ő es mind azt teszi), illetőleg a negatív kifejlet (kárt vallasz) lehetőségét is.

5. Különleges és központi szerepű e levélben az akarige és származéka az akarat. A szöveg súlyponti kérdése a két személy, adós és hitelező akaratának ütközése, kettejük erejének összemérése. Az akar/akarat a levélben tíz alkalommal fordul elő. Érdemes megfigyelni, hogy hol: az első előfordulás csak a szöveg közepe környékén bukkan fel, hogy aztán egyre hangsúlyosabban jelenjék meg mind a tanácsadó személyek, mind a levélíró saját szavaként. Itt is megtaláljuk a szó környezetében a pozitív kifejlettel való biztatást (ha kegyelmed odamegyen, és ebbe neki akaratját teszed, ô es mindazt teszi vala, mit kegyelmed akar), illetőleg a nem teljesítés esetén a negatív (ha Mihály uram akarja, még két vagy három esztendeig elvontathatja az fizetést) következményeket. A javaslattevő forma kiegészül négy esetben egy elökészítő stratégiával is, melynek megformálása az egyebet benne ne tégy formulával történik. Azok a stratégiai elemek tehát, amelyek Szilinél is mint a magyar nyelvű kérést megfogalmazók stratégiái jelennek meg, már a 16. század elején is a fontosak és gyakran alkalmazottak közé tartoztak.

Tekinthetjük e szöveget a grice-i maximák fényében egy sajátos egyirányú társalgásnak is. Ekkor implikatúraként az „ezzel az emberrel nem lehet másképp célt érni”, illetőleg „ennyi pénzt nem hagyhatunk elveszni” közös gondolat állhat. Szükséges tehát az együttműködés a címzett részéről. A szöveg a „hallgatónak” ezt az együttműködését kívánja elősegíteni, motiválni, kiváltani. Felmerülhet azonban az a kérdés, hogy nem fordul-e önmaga ellentétébe, vagyis nem vált-e ki ellenkező hatást a mennyiségi maxima tekintetében a menjen el, tegye akaratját formák túlzott alkalmazása. És ami a mód maximáját illeti: eléggé tömör-e, nem szükségtelenül bőbeszédü-e ez a szöveg? Az ismétlés nem vált-e át redundanciába? Az igazság az, hogy nem tudjuk, elérte-e célját a levélíró, anyja valóban megtette-e a kívánt gesztust. Ám a szöveg valódi értékeléséhez ez az ismeret nem is fontos. A mélyebb értékeléshez a 16. század eleji társadalmi környezet és kommunikációs mód ismerete szükséges: a korabeli levelezés ismeretében érthetjük meg a levélíró szándékát. E levelezés egyik leggyakoribb kifejezése a levelek kezdő részében a „kegyelmed levelét megértettem” formula. Ez a mondat elárulja a gondolatok megértésének, az üzenetek megfejtésének nehéz munkáját: a központozás nélküli, a kis- és nagybetüt alig megkülönböztető, a diktálás következtében a mindennapi beszéd lendületét, de ugyanakkor a szerkesztetlenségét is tükröző korabeli levelek ismeretében értékelhetjük a maga teljességében szövegünket, amely a levélíró szándéka szerint csak így, a kérés, unszolás számunkra mintegy túlzásba vitt ismétlésében megnyilvánuló zsúfoltsággal érhette el a kívánt hatást.

\section{Hivatkozások}

Austin, John Langshaw 1990. Tetten ért szavak. Fordította Pléh Csaba. Budapest: Akadémiai Kiadó.

Bácsi Enikő 2015. A kérési szándék megjelenési módjainak vizsgálata egy 16. század második felében folytatott házastársi levelezésben. In P. Kocsis Réka - Szentgyörgyi Rudolf (szerk.) Anyanyelvünk évszázadai 1. Budapest: ELTE Magyar Nyelvtörténeti, Szociolingvisztikai, Dialektológiai Tanszék. 75-87.

Hegedűs Attila 1986. Történeti szociolingvisztika? Magyar Nyelv 82:438-441. 
Hegedűs Attila - Papp Lajos (szerk.) 1991. Középkori leveleink. Budapest: Tankönyvkiadó.

Koós Eszter 2008. A kérés beszédaktusa boszorkánypereinkben. In Kozma Judit Lisznyai-Mindák Cecilia - Ludányi Zsófia (szerk.) Félúton 4. Budapest: ELTE Mai Magyar Nyelvi Tanszék. 1-13.

Krepsz Valéria 2015. A kérés beszédaktusa középmagyar kori főnemesek és közrendűek levelezésében. Magyar Nyelv 111/2:162-173.

Németh Miklós 2008. Nyelvi változás és váltakozás társadalmi és múveltségi tényezők tükrében. Nyelvi változók a XVIII. században. Szeged: Szegedi Tudományegyetem Juhász Gyula Felsőoktatási Kiadó.

Sárosi Zsófia 1985. A személyek közötti viszony tudatosítása és nyomatékosítása néhány XVI. századi misszilisban. Magyar Nyelv 81:334-342.

Sárosi Zsófia 2015. Pragmatika, szociopragmatika, udvariasságkutatás a magyar nyelvtörténetben. Magyar Nyelv 111/2:129-146.

Szili Katalin 2002. A kérés pragmatikája a magyar nyelvben. Magyar Nyelvör 126/1:12-30.

\section{A szerzőről}

Hegedűs Attila a PPKE Magyar Nyelvészeti Tanszék vezetője, habilitált egyetemi docens. Kutatási területei a magyar nyelv története, a magyar dialektológia és a névtan.

Elérhetősége:hegedus.attila@btk.ppke.hu 